ISSN 1112-9867

http://www.jfas.info

\title{
PREDICTION OF DIAGENESIS AND RESERVOIR QUALITY USING WIRELINE LOGS: EVIDENCE FROM THE UPPER TRIASSIC (RAETHIAN) FLUVIAL RESERVOIR TAGS - TOUAL FIELD, GASSI TOUIL AREA, SE ALGERIA
}

\author{
E. Mazouz ${ }^{1,2 *}$, M. Hamimed ${ }^{3}$, A. Yahiaoui ${ }^{1}$, M.A.K. El-Ghali ${ }^{4}$ \\ ${ }^{1}$ Batna 2 University, Batna, Algeria \\ ${ }^{2}$ Larbi Ben M'hidi University, Oum El Bouaghi, Algeria \\ ${ }^{3}$ Cheikh Larbi Tebessi University,Tebessa, Algeria \\ ${ }^{4}$ Sultan Qaboos University, Mascate, Oman
}

Received: 21 September 2016 / Accepted: 16 April 2017 / Published online: 01 May 2017

\begin{abstract}
Reservoir quality is mainly controlled by environment deposit type and diagenesis processes. To investigate such subject we usually proceed to microscopic techniques. Absence of outcrops and missing of core samples let us use conventional wireline logs and core lab measurements as primary data. Direct lecture of well logs calibrated by core photos and wellsite description, well logs correlation and cross plots were our main methodology axis. Target of this study is the fluvial Shaly Sandstones of Upper Triassic (Rhaetian) reservoir (abreviated in French; TAGS) located in Toual field - SE of Algeria. The present investigation confirms the absence of clean sandstone levels in the studied reservoir. It detects also the presence of halite and clays (Illite) as cements in sandstone. The influence of illite on permeability was confirmed whereas porosity is less affected.
\end{abstract}

Keywords: Diagenesis; Reservoir Quality; Well logs; Fluvial System; Triassic; Toual.

Author Correspondence, e-mail: emazouz@yahoo.fr

doi: http://dx.doi.org/10.4314/jfas.v9i2.13 


\section{INTRODUCTION}

Recognizing combined effect of sedimentary processes (weathering, transport and deposition) as a part and diagenesis as another part on reservoir quality is a key knowledge in petroleum reservoir characterization. Reservoir bodies' geometry is closely related to depositional environment which are known by sedimentary processes studies. Diagenesis for its part controls internal arrangement of reservoir rocks (Porosity and permeability).

\subsection{Previews studies \& actual study objective}

Researches on Shaly Sandstones of Upper Triassic (Rhaetian) reservoir (abreviated in French: TAGS - Trias Argilo-Gréseux Supérieur) seem rare comparatively with those on TAGI (Lower Triassic, Ladinian to early Carnian); this less importance is probably due to the reduced extent of TAGS compared with TAGI. TAGS is secondarily cited when investigating TAGI. Only depositional environment and general reservoir information are given. No diagenesis investigations were conducted. [1] notes that TAGS reservoir is rich sand, its fluvial sandstones in the southwestern portion of the Berkine basin are excellent, but without any explanations. [2] and [3] in their reports indicate that TAGS has good petrophysical properties in almost fields. [4] details TAGI diagenesis in Ourhoud field (Berkine Basin) where TAGS is completely absent in stratigraphy. With the aim of helping to close this gap, this paper predicts some aspects on TAGS diagenesis using wireline logs.

Usually diagenesis is studied with microscopic techniques. In case of lack of physical data (outcrops and/or core samples), commonly wireline logs data are used. Its results were successful in almost of cases. In this perspective, we tried to investigate the influence of diagenesis processes on reservoir quality of a fluvial shaly sandstones reservoir using well log data calibrated with core photos.

\subsection{Presentation of TAGS}

The studied reservoir is located in Toual field SE of Algeria (recognized by 25 wells from 1962 till present). TAGS with about $100 \mathrm{~m}$ thickness, is mainly composed by fluvial channels deposits in its lower part and over banks deposits in its upper part. TAGS is overlaying Trias Carbonaté formation (shallow marine deposits - sabkha). As reservoir, it is sealed by Trias argileux and Trias salifère formations (shallow marine deposits - sabkha). 


\subsection{Geological setting}

Structurally, Algerian territory is divided into two main geological domains; Alpine domain to the north and Saharan platform domain to the south (Fig. 1.). However, the Saharan platform domain contains two petroleum provinces; eastern and western province. The eastern province is composed of Amguid-El Biud-Messaoud uplift, Berkine Basin, Oued Mya Basin and Illizi Basin [3]. The Amguid-Messaoud uplift encompasses the Toual field (Fig.1. and Fig.02.) in which is producing from TAGS Formation. TAGS in Toual field is located in N-S oriented anticline with faults network in same direction (Fig. 3. and Fig. 4.). Toual structure has been created as consequence of the transpressional deformation along $\mathrm{N}-\mathrm{S}$ faults in Amguid-El Biud region during the Austrian phase. Due to the Alpine orogenesis that followed Austrian one, the existing structure was folded into the anticline [1].

Stratigraphically, Toual field is composed of a thick sequence from Cambrian to Quaternary deposits ([2], Fig. 5.). Paleozoic sub-sequence is represented by an alternation of detrital rocks (mudstones, sandstones, quartzite, and conglomerates) ([2], [3]). The Mesozoic succession is divided into two sequences. The first began from Triassic to middle Cretaceous with continental to shallow marine deposition (which includes the studied reservoir), where the second extend to late Cretaceous with shallow marine carbonates [5]. The Cenozoic formations are represented by a variety of clastic sediments from various Mio-Pliocene depositional environments ([2], [3]). First Triassic deposits in the area following Hercynian unconformity was Trias Argilo-Gréseux Inférieur (TAGI). Its basal part is dated in the northern of Berkine Basin, by palynology, Ladinian to late Carnian ([6], [1]). Older Triassic formations (Anisian) than TAGI are observed in outcrops in Zarzaitine, extreme Algerian south east [7]; TAGI is overlayed by the Trias carbonaté (Carnian to Norian) and TAGS (Rhaetian) [1].

Depositional environment of TAGS correspond to fluvial system from bottom to top it changes from braided and meandering system to thin channelized sand sheets included in thick muddy intervals characterizing shallow marine sabkha. Decreasing in sand amount is from SW to NE ([2], [3], [1]).

With structural traps type (Anticlines), TAGI and TAGS are the main Triassic reservoirs in the 
area. They are represented by fluvial shaly sandstones. TAGI is limited by Silurian shale as a lower seal and Trias carbonaté shale as upper one. TAGS is included between Trias carbonaté and Trias argileux as lower and upper seals respectively. The main source rock in the area is Silurian black shale [2]. As noted by [2] and [3], Petrophysical report of well TOU7 [8] indicates that average petrophysical parameters of TAGS classified it as a good reservoir (Table 1).

Table 1. Average petrophysical parameters of TAGS in TOU7 [8]

\begin{tabular}{ccccc}
\hline $\begin{array}{c}\text { Gross Reservoir } \\
\text { Thickness }\end{array}$ & $\begin{array}{c}\text { Net Reservoir } \\
\text { Thickness }\end{array}$ & $\begin{array}{c}\text { Average } \\
\text { Porosity }\end{array}$ & $\begin{array}{c}\text { Average Clay } \\
\text { Volume }\end{array}$ & $\begin{array}{c}\text { Average Water } \\
\text { Saturation }\end{array}$ \\
\hline $100 \mathrm{~m}$ & $41,91 \mathrm{~m}$ & $14 \%$ & $7 \%$ & $32 \%$ \\
\hline
\end{tabular}

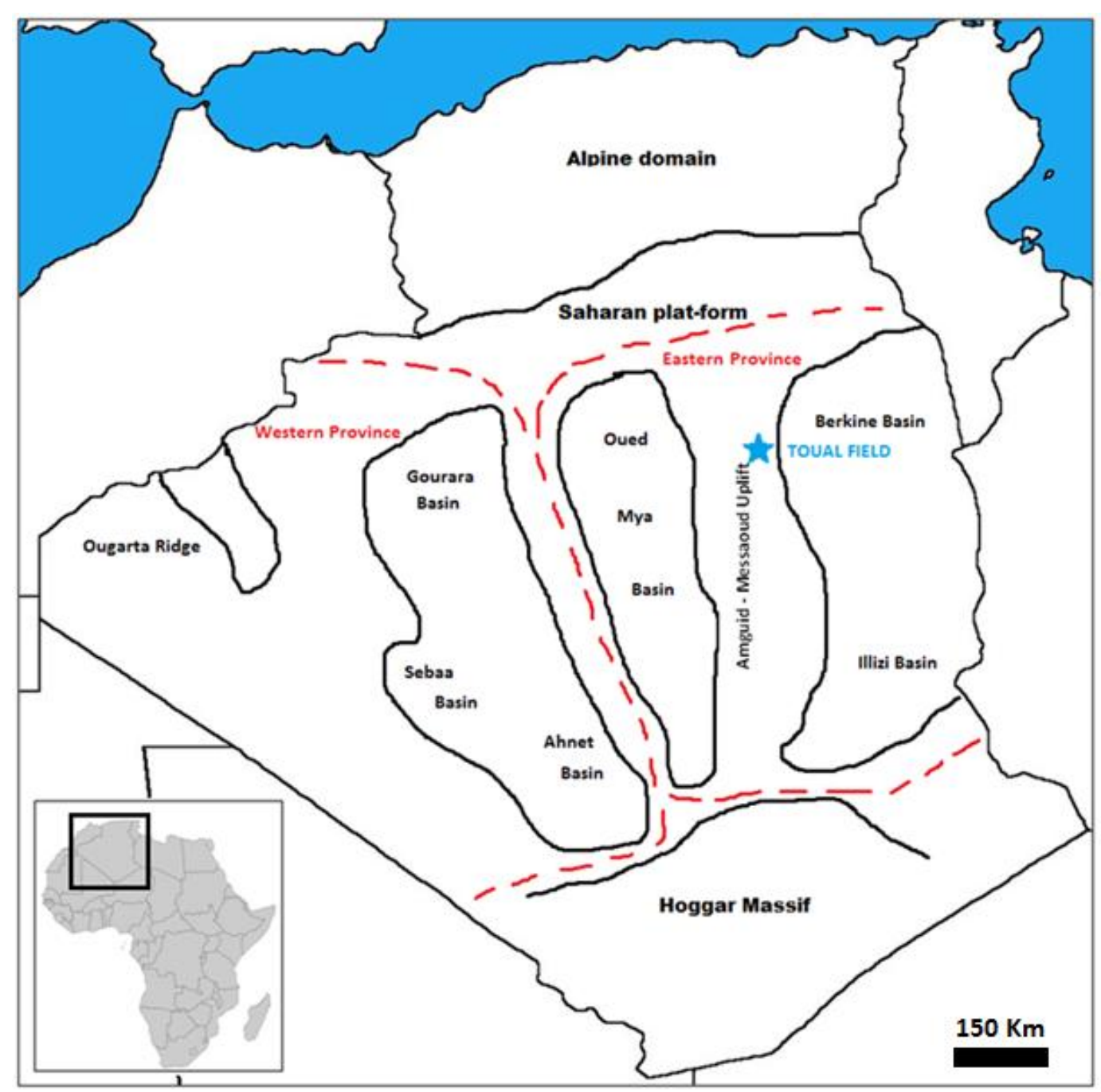

Fig.1. Schematic map showing the main geological domains of Algeria (Based on [3]) 


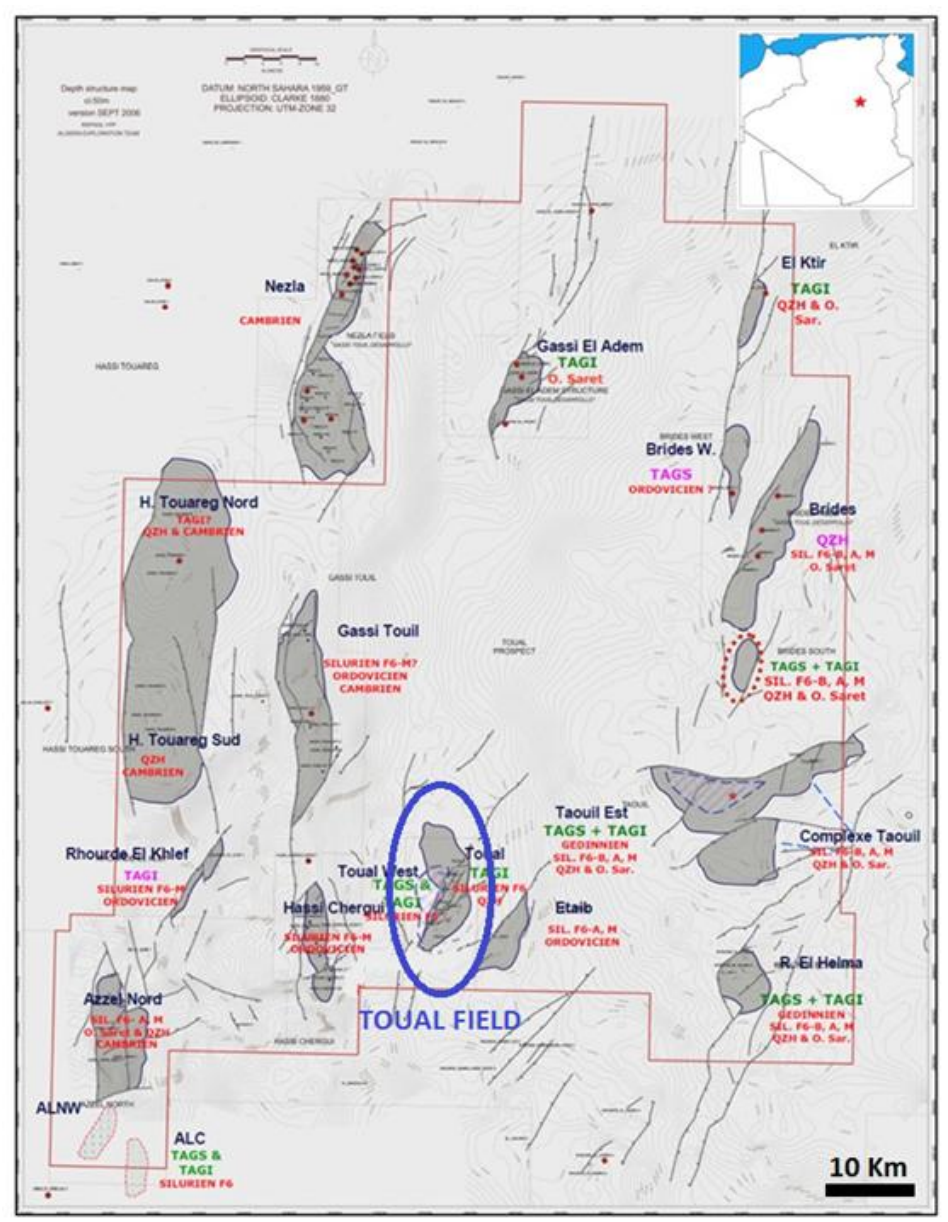

Fig.2. Depth structure map showing the position of Toual field in Gassi Touil area. SE Algeria. [9]

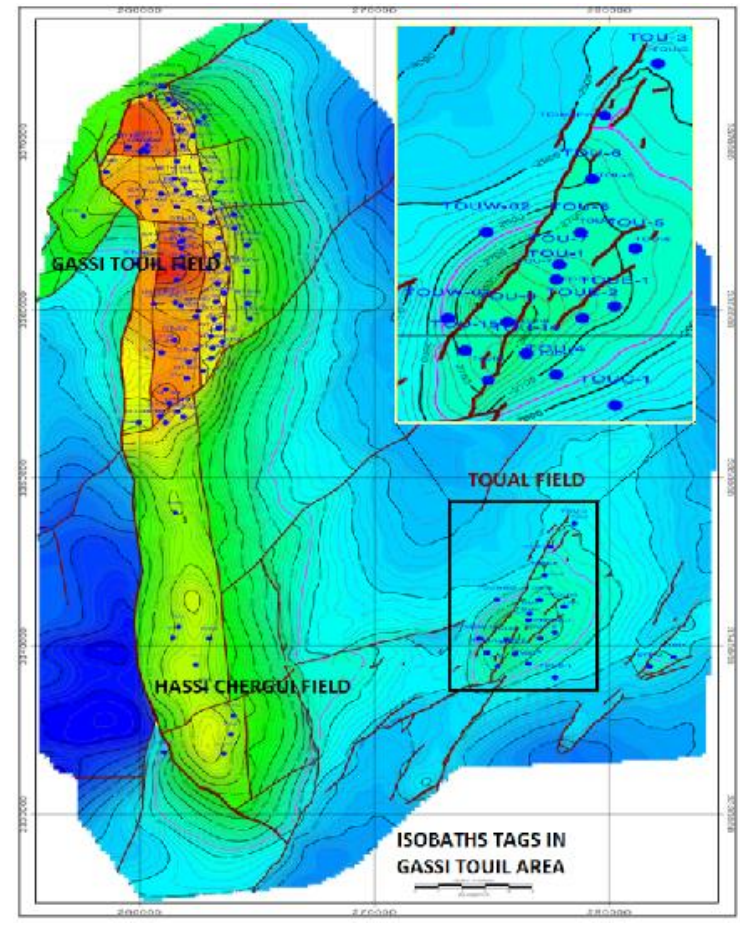

Fig.3. Isobaths map of TAGS in Toual, showing anticline structure with drilled wells [10] 


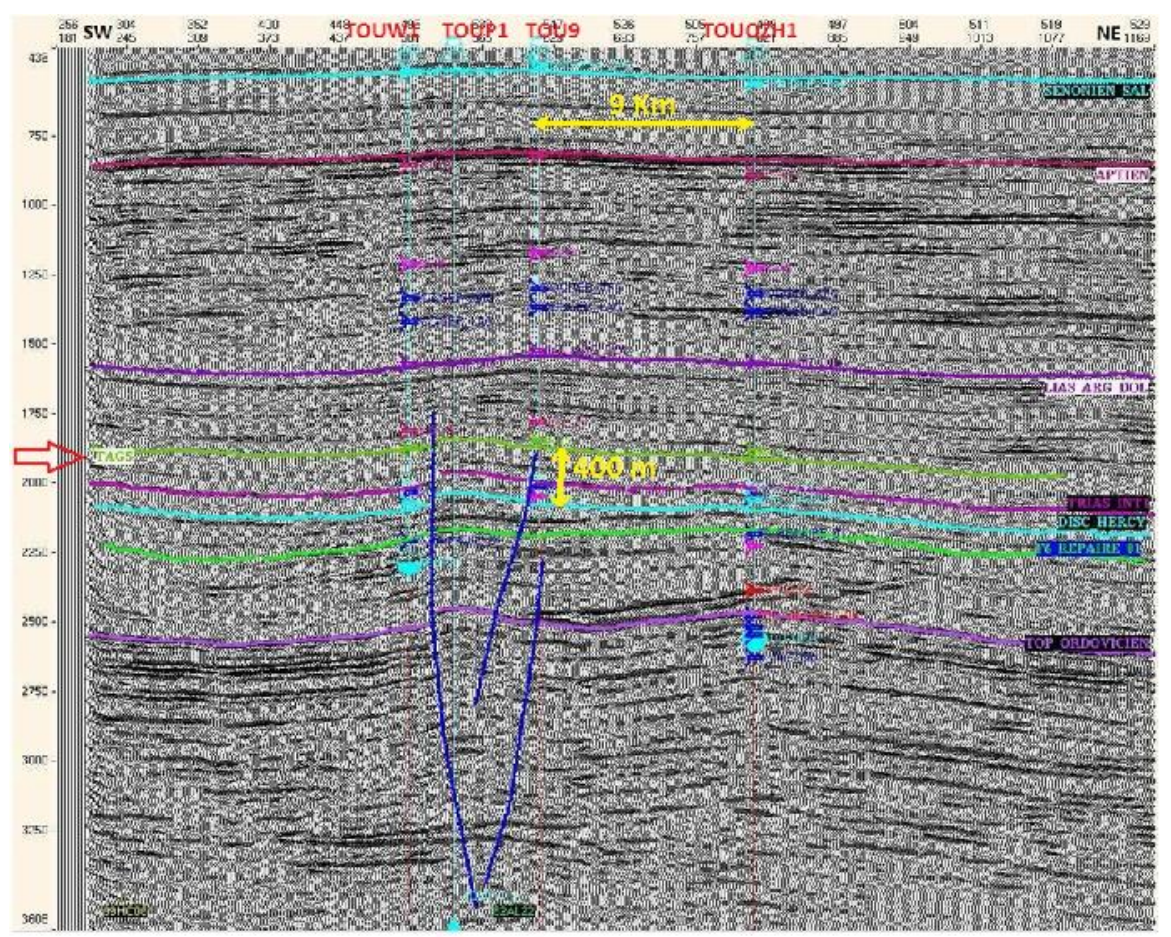

Fig.4. Seismic profile cross SW-NE showing Faults network - Toual field [9]

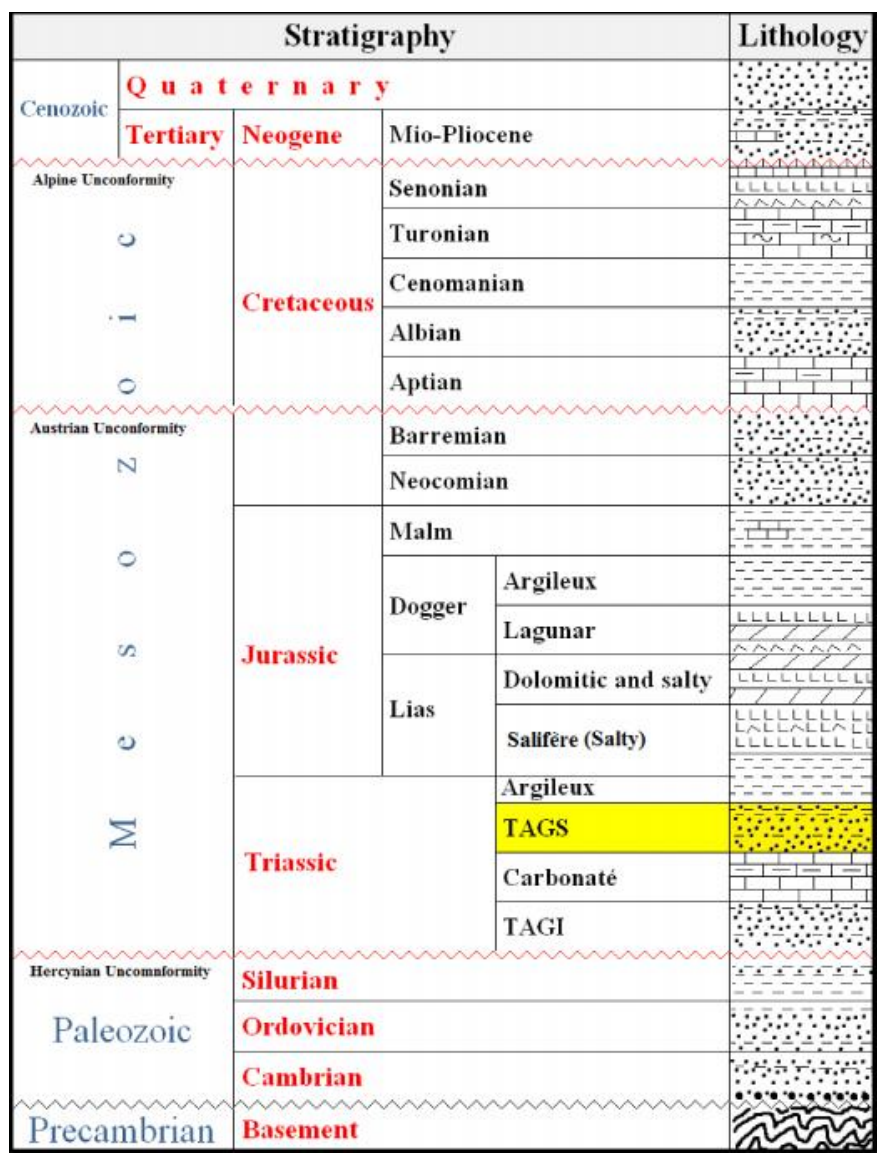

\section{LEGEND}

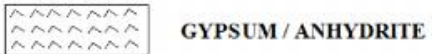

LLLLLLLLLLLLLLS SALT

I, T, DOLOSTONE

LIMESTONE

$\approx \approx \approx \sim \approx \sim$ MARL

CLAYSTONE

$\because \because \because \because 6$ SANDSTONE

$\because \because \because \because \because$ congLoMERATE

年告 METAMORPHIC AND

Fig.5. Lithostratigraphic column of Toual field based on [2], Curved lines represent conformities from bottom to top: Hercynian, Austrian and Alpine 


\section{METHODS}

From 20 wells or so, the available data collected to conduct this study are mainly; wireline logs of three wells, core photos of two wells, five wellsite core description reports and 15 masterlogs.

After environmental correction of Caliper, Spectral Gamma Ray, Sonic and Density logs we proceeded to establish composite log. The simple lecture of this log gives us idea on facies distribution (sandy and shaly levels). This allowed us also to split TAGS on two distinct members, a sandy member in its bottom and a muddy member at the top. Basing on Shell method [11], GR shapes can define environment deposits (bell shape of GR for example can correspond to a meandering channel; cylindrical shape could be a braided channel). Lecture of sonic and density responses combined with GR may indicate sandstone hardness which has relation with cement type in sandstone.

The second step was calculating shale volume from GR, this allow us to discriminate sandy bodies from shaly ones when using cross-plots. We can then limit analysis following shale volume. The cutoff used in all cross-plots is $50 \%$ (it means every shaly sandstone level containing above than $50 \%$ of shale is automatically excluded).

To confirm interpretation of conventional logs lecture, we have established a couple of three dimensional cross-plots (GR-DT-RHOB) for each member of TAGS. This can distinguishes several types for the analyzed sandstone layers, represented in cross-plots by zones. Every zone corresponds to a specific rock type.

From MRIL (Nuclear magnetic resonance log of Halliburton), we have used permeability and porosity registered logs versus potassium concentration from SGR log to create a couple of semi-logarithmic cross-plots for each member of TAGS also. This method can informs us on influence of illite on reservoir quality.

A correlation between gas mobility values in TAGS (brought from Reservoir Characterization Instrument (RCI) results), core permeability and porosity log and core photos, let us confirm the compaction degree of sandstone layers with low permeability at TAGS top.

Additional information relating to this research was collected from surface logging master $\operatorname{logs}$, and reports presented in references. 
We note that Caliper and Density logs are combined in one track to show influence of borehole diameter on density. We have observed that density log was not affected by borehole diameter, whereas many shaly picks show caving effect but this doesn't influence on the present work.

\section{RESULTS AND DISCUSSION}

\subsection{Depositional environment}

As noted in literature ([2]; [3]; [1]) and using shell GR interpretation method [11], first observation on GR logs indicates from bottom to top (Fig. 6. and Fig. 7.):

- Cylindrical shapes of sandstone bodies can be interpreted by braided channel deposits.

- Bell shapes of sandstone bodies may correspond to meandering bar deposits.

- Muddy interval at the top of TAGS with thin channelized sandstone sheets can be related to fluctuation sea level. This may corresponds to change from fluvial system to shallow marine sabkha reigned in Trias argileux (Upper seal of TAGS). 


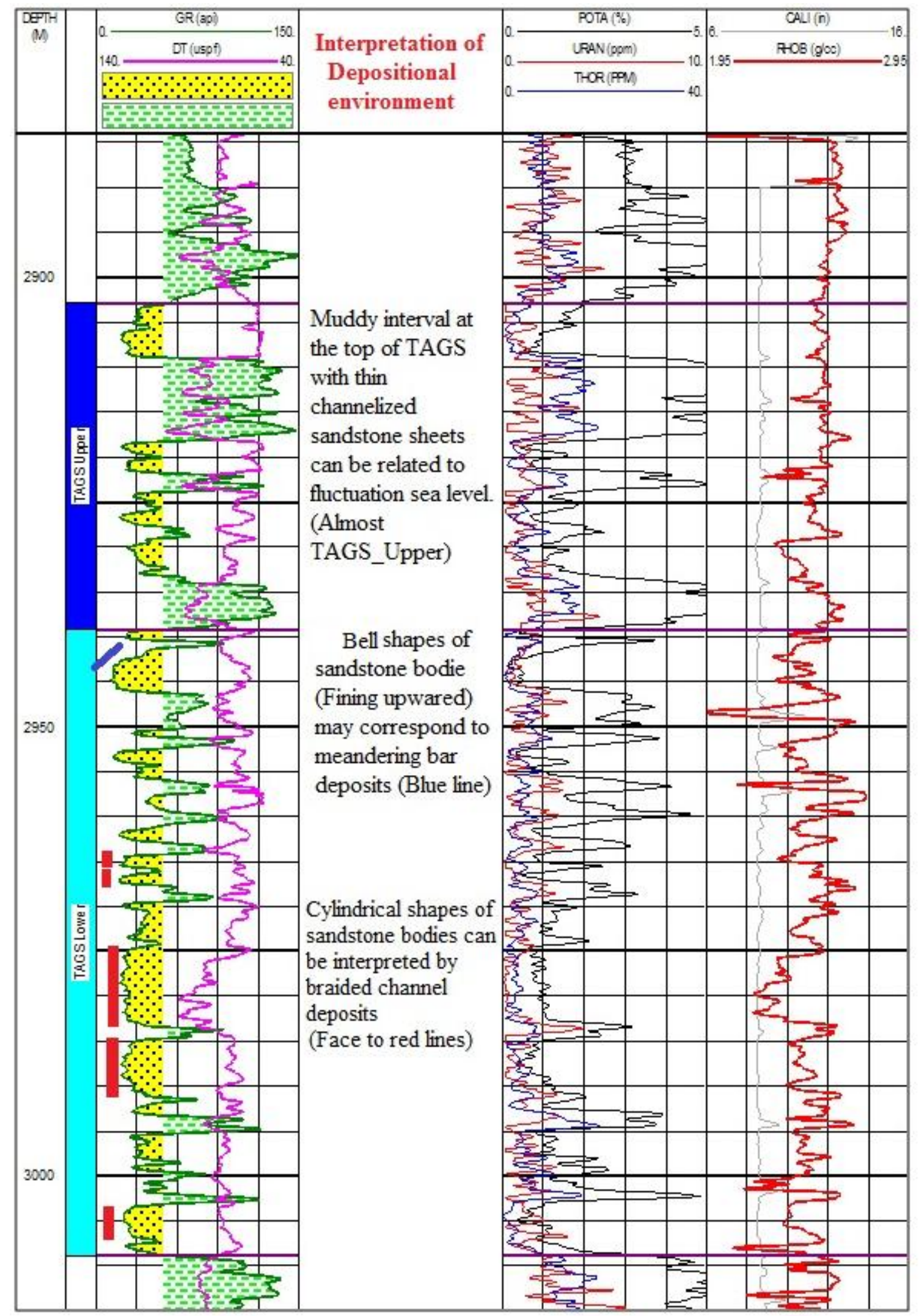

Fig.6. Composite log for TAGS Formation in Well TOU14 showing Depositional environment using GR, we note an heterogenic behavior of DT and RHOB in sandstone and good Caliper which don't affect RHOB 


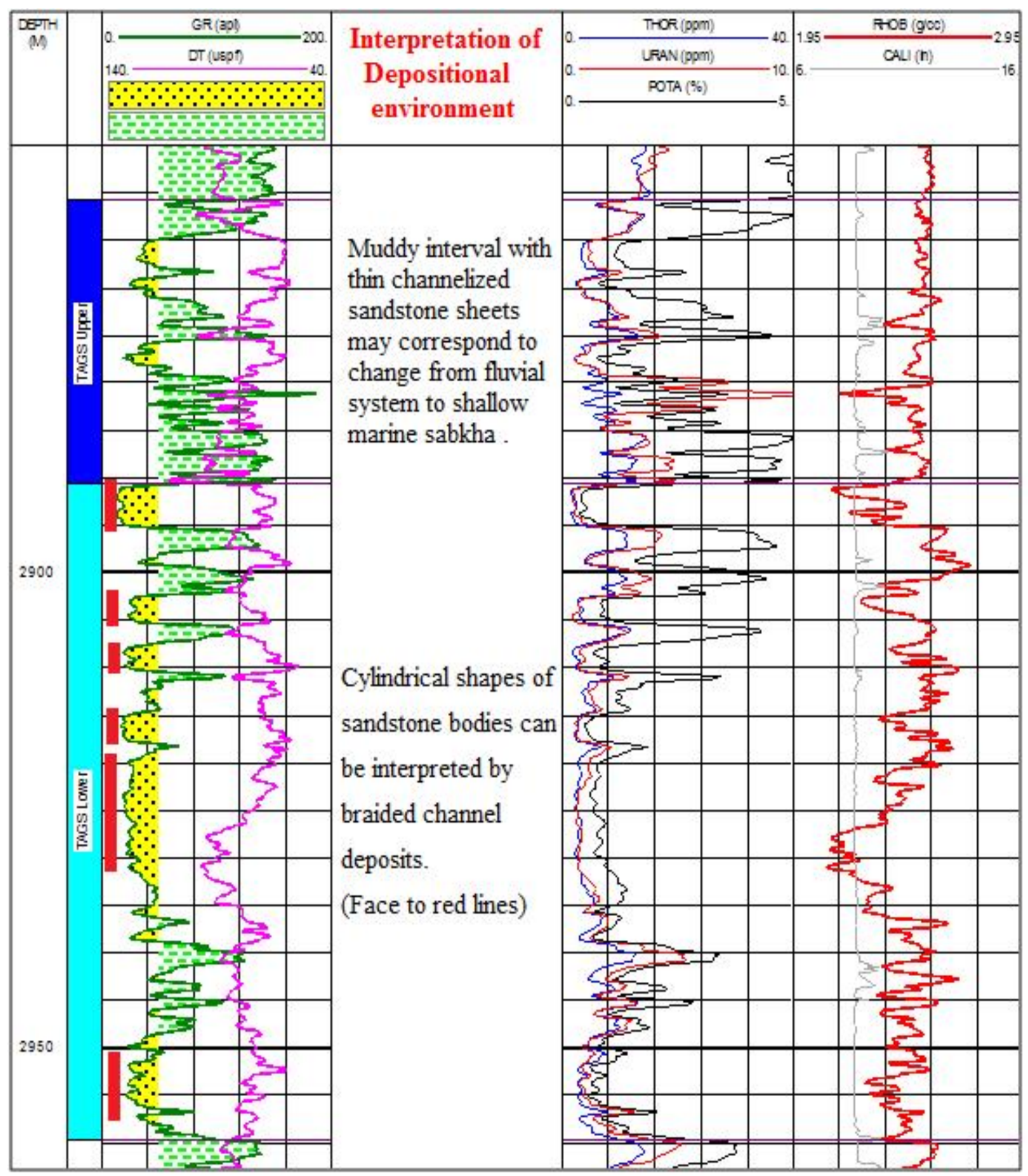

Fig.7. Composite log for TAGS Formation in Well TOU15 showing Depositional environment using GR, we note an heterogenic behavior of DT and RHOB in sandstone and good Caliper response which doesn't affect RHOB

\subsection{Reservoir diagenesis}

Heterogenic behavior of DT (Sonic tool response) and RHOB (Density tool response) in front of many sandstone levels in both wells TOU14 and TOU15 (Fig. 6. and Fig. 7.), may indicates the presence of some minerals in sandstone other than quartz. 
To confirm this hypothesis we have established two 3-dimensional cross-plots (GR, DT and RHOB) in each well for TAGS Upper and TAGS Lower (Fig. 8a, 8b, 9a and 9b.). Following petrophysical responses, population is divided into three zones in each cross-plot (Reference values are based on [11]):

$\underline{\text { Zone A }}$, represent clean sandstones which are absent or extremely rare in both parts of TAGS. Clean sandstones have usually low sonic (DT=56 $\mu \mathrm{s} / \mathrm{f}$ ), their density (RHOB) is about 2.64 $\mathrm{g} / \mathrm{cc}$ and Gamma Ray response is low (GR< $40 \mathrm{API})$.

$\underline{\text { Zone B }}$, shows logic Gamma Ray values for sandstones (GR<50 API) for whole reservoir, high sonic $(57<\mathrm{DT}<100 \mu \mathrm{s} / \mathrm{f})$ in Lower TAGS and less in Upper TAGS $(57<\mathrm{DT}<77 \mu \mathrm{s} / \mathrm{f})$. Density is included between 2.60 and $2.61 \mathrm{~g} / \mathrm{cc}$ (Red points). This can be attributed to presence of salt cement in sandstone which increases DT and decrease RHOB. (Halite usually has: $\mathrm{DT}=67 \mu \mathrm{s} / \mathrm{f}$ and $\mathrm{RHOB}=2,04 \mathrm{~g} / \mathrm{cc}$ )

$\underline{\text { Zone } \mathbf{C}}$, shows high GR and high DT in whole reservoir with nearly the same interval of density in the two wells. We can attribute the high GR values to the presence of clay (possibly illite) in sandstones if we remark relatively the high concentration of potassium in some sandstone levels showed by spectral GR $\log$ (Fig. 6. and Fig. 7.). This can be confirmed by petrophysical interpretation of TOU4 well ([12]; Fig. 10.), which showing presence of illite in whole TAGS interval.
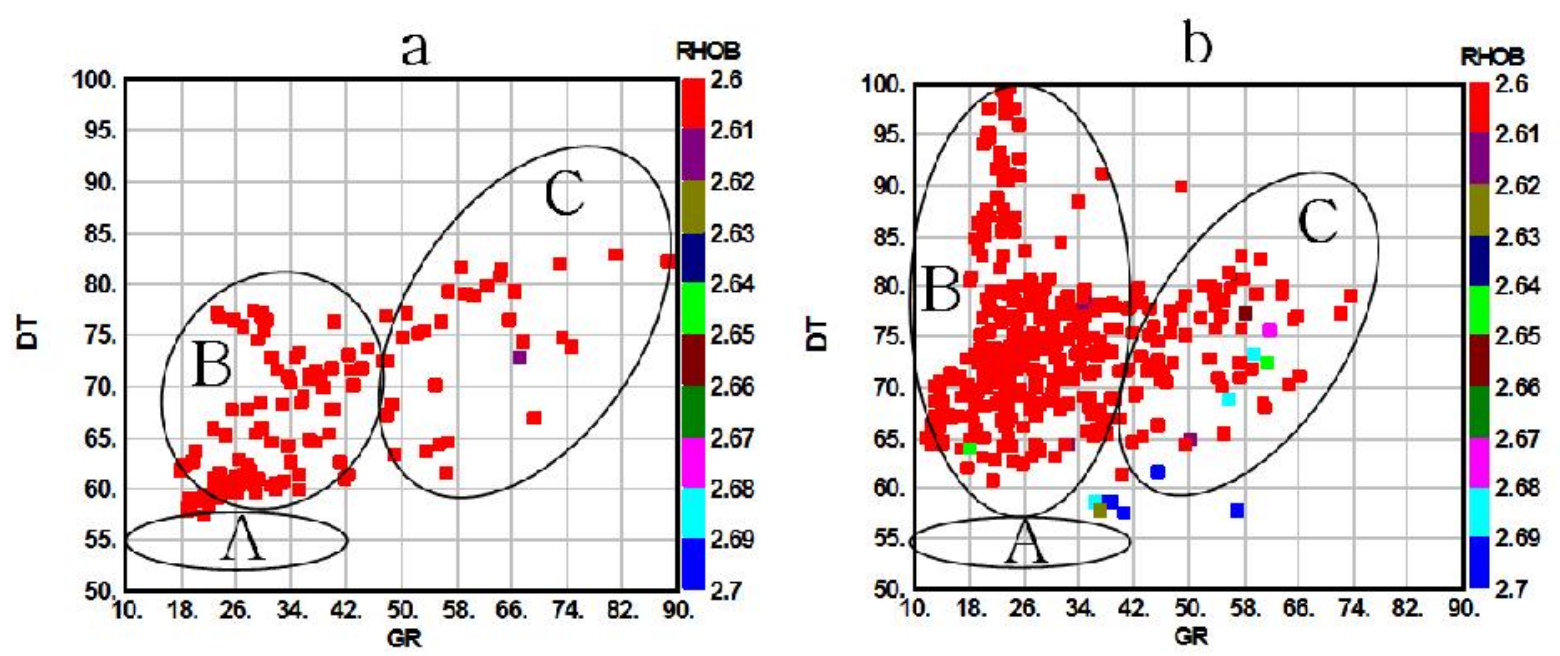

Fig.8. Cross-plots (GR, DT and RHOB) for TAGS Upper (a) and Lower (b) - Well TOU14 

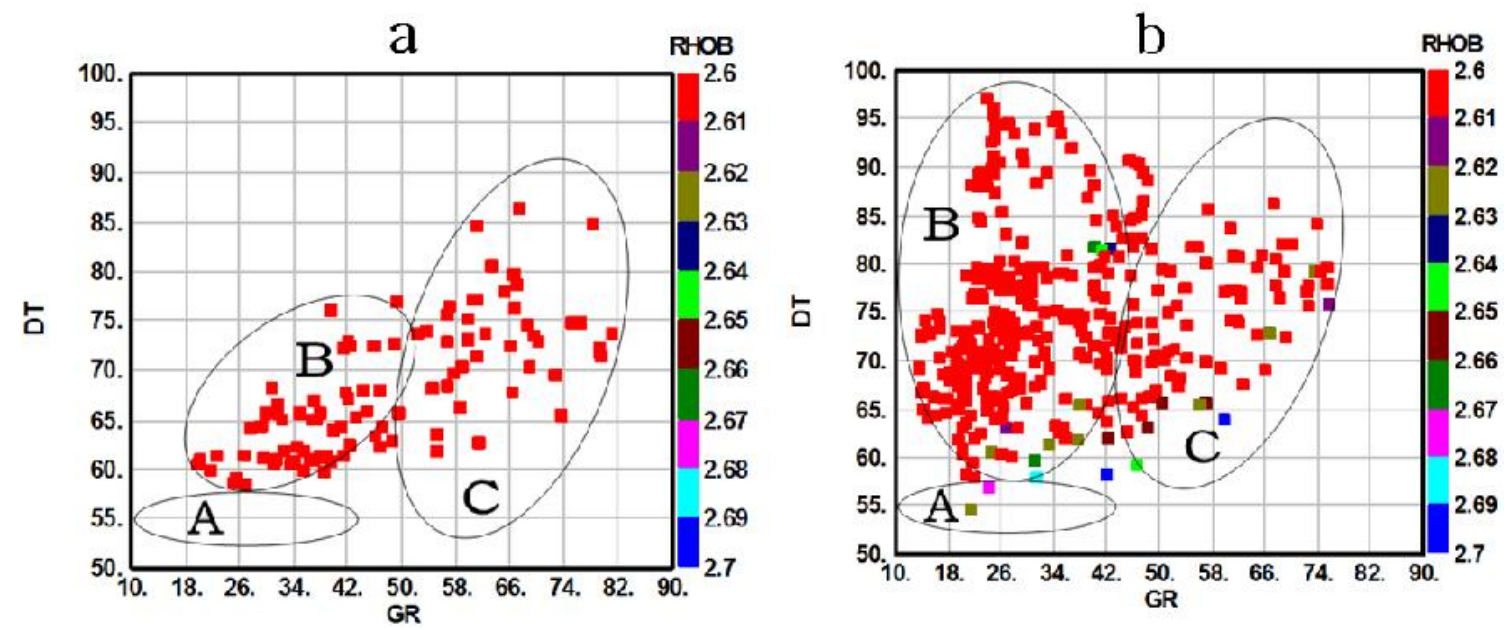

Fig.9. Cross-plots (GR, DT and RHOB) for TAGS Upper (a) and Lower (b) - Well TOU15

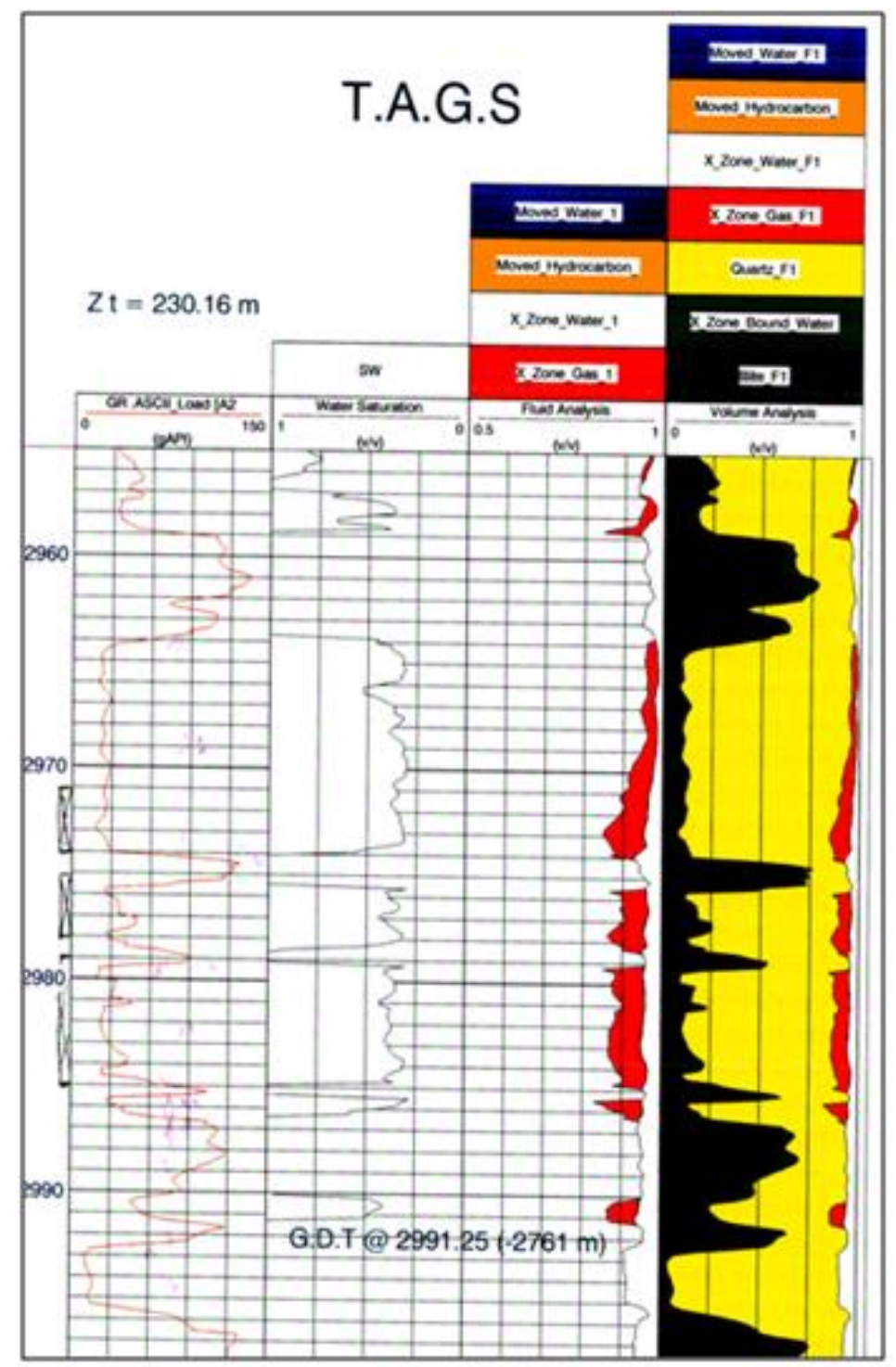

Fig.10. Petrophysical interpretation of TOU4 showing presence of Illite in sandstone intervals (Black color) [12] 


\subsection{Diagenesis effect on reservoir quality}

\subsubsection{Prediction from SGR and NMR logs: Illite reduction of permeability}

Presence of clay (illite) affects extremely reservoir permeability. Its bridging micro-structure reduces permeability. [11],

Nuclear Magnetic Resonance (NMR) log recorded in the TOU14 and TOU15 wells shows this influence. NMR permeability, abbreviated (T2KC), don't exceed 100 md. (Fig. 11.)

In both wells TOU14 \& TOU15, Figure (12) shows a cross plot for whole reservoir interval between NMR permeability (T2KC in $\mathrm{mD}$ ) and Potassium concentration (POTA in \%).

We observe that a reverse regression is obvious with low correlation coefficient, permeability decreases when potassium concentration (representing illite) increases.

Figure (13) shows another cross plot for whole reservoir level also, but in this case between NMR porosity (T2PC in \%) and Potassium concentration (POTA in \%).

A normal regression with relatively high correlation coefficient are observed, porosity is decreasing when potascium concentration decreases. Which prove that illite presence in sandstone does not highly affect porosity (in both wells TOU14 \& TOU15).
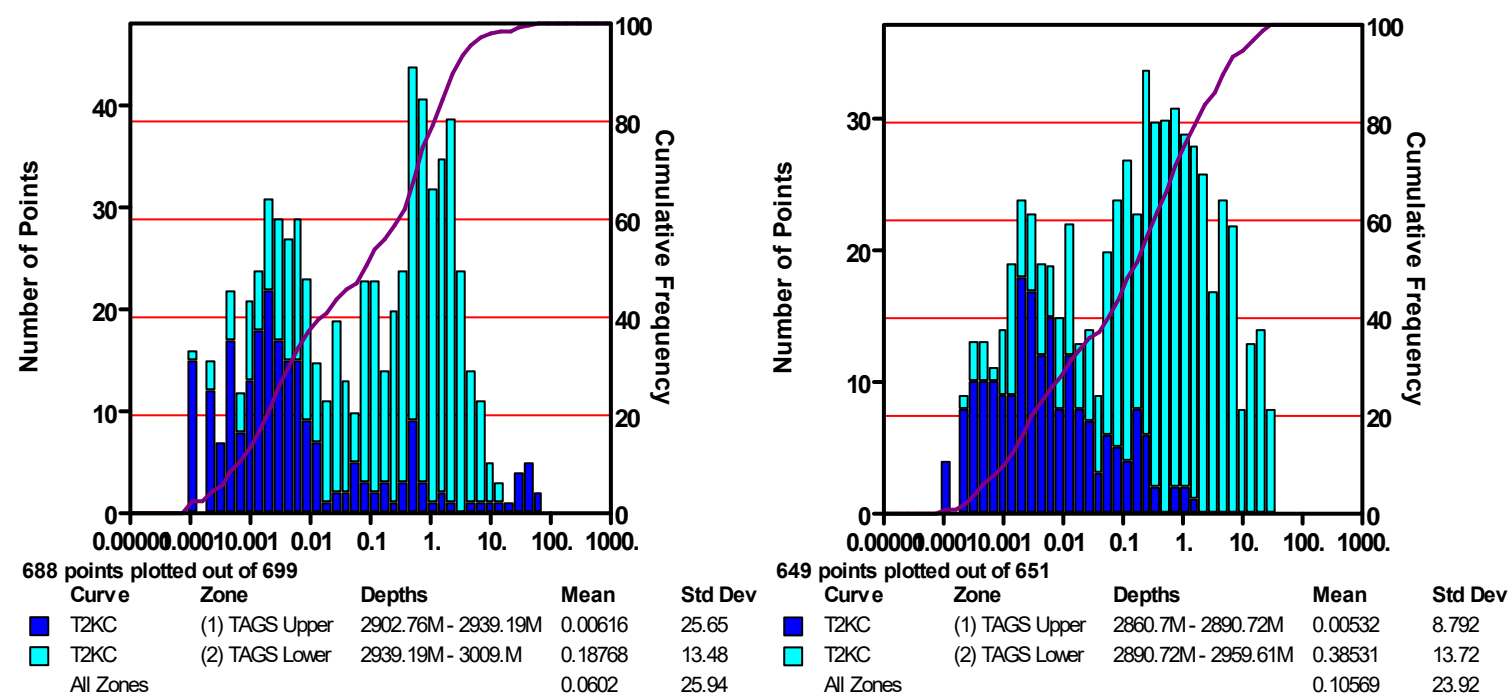

Fig.11. NMR Permeability histograms for TAGS Formation in Well TOU14 (Left) and Well TOU15 (Right) showing that permeability value doesn't exceed $100 \mathrm{mD}$ for both intervals lower and upper. 

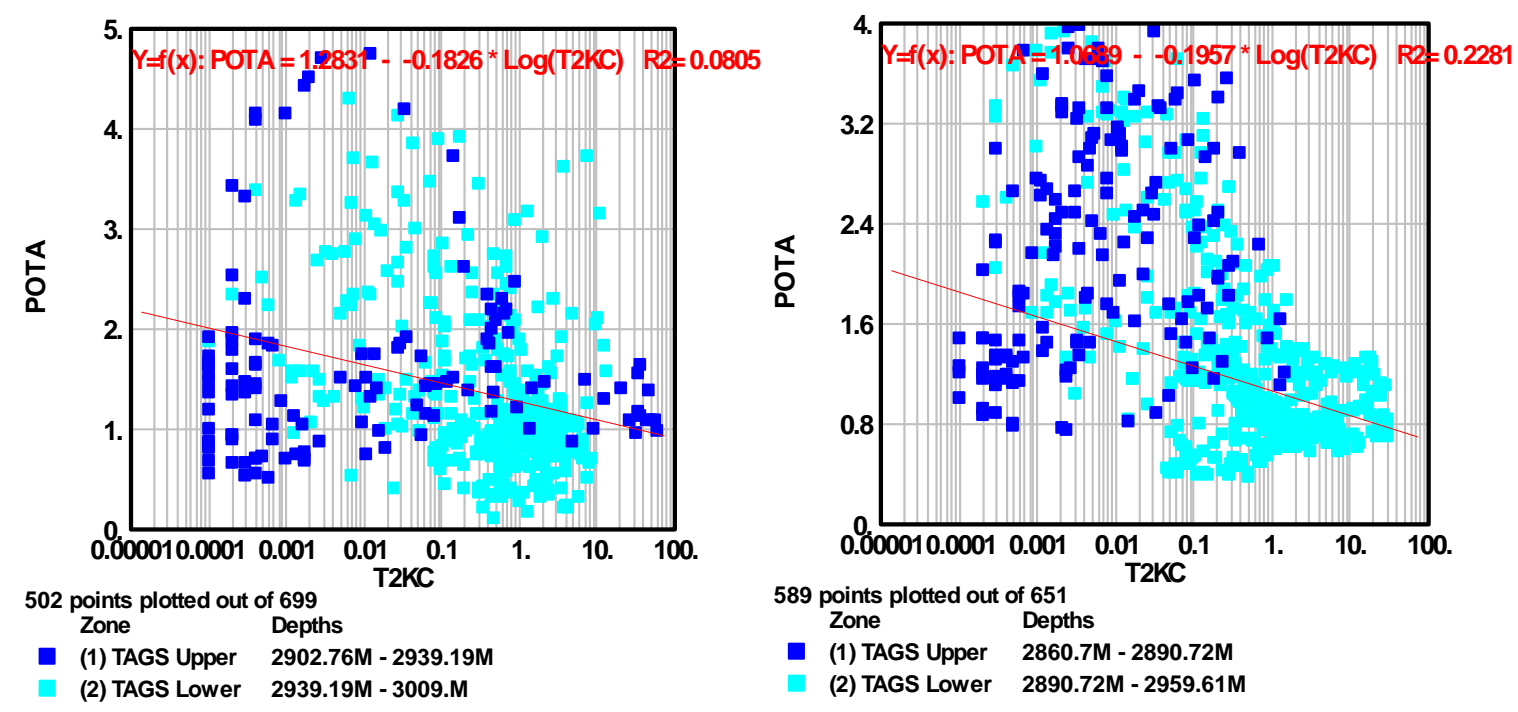

Fig.12. NMR Permeability VS Potassium for TAGS Formation in Well TOU14 (Left) and Well TOU15 (Right) showing reverse regression indicating influence of potassium presence in sandstones on permeability
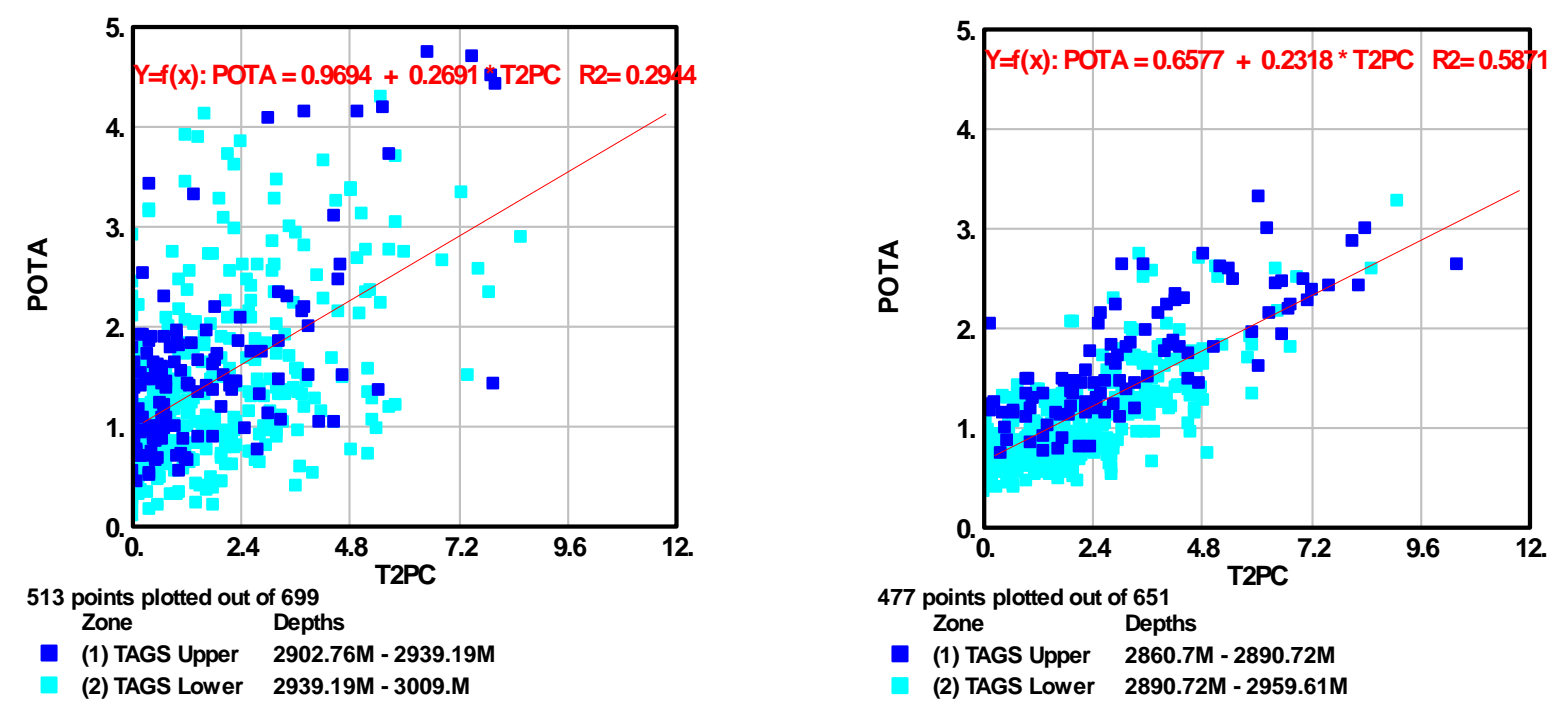

Fig.13. NMR Porosity VS Potassium for TAGS Formation in Well TOU14 (Left) and Well TOU15 (Right) showing normal regression indicating non influence of potassium presence in sandstones on porosity especially in well TOU15 $\left(\mathrm{R}^{2}=0,59\right)$.

\subsubsection{Prediction from pressure formation test logs: Impermeability of Top TAGS}

Results of pressure test logging (Reservoir Characterization Instrument of Baker) below (Table-2) show low permeability to tight reservoir in points tested in Top TAGS (in bold character). Mobility is equivalent to permeability over viscosity (MilliDarcy/CentiPoise). 
Table 2: Results of pressure test logging (RCI). Low to very low permeability in top TAGS

(Bold character)

\begin{tabular}{rrl}
\hline DEPTH $(\mathbf{m})$ & MOBILITY(Md/cp) & \multicolumn{1}{c}{ REMARKS } \\
\hline $\mathbf{2 ~ 8 8 7 , 6 0}$ & $\mathbf{0 , 5 0}$ & TIGHT RESERVOIR \\
$\mathbf{2 ~ 8 9 0 , 5 0}$ & $\mathbf{0 , 4 0}$ & TIGHT RESERVOIR \\
$\mathbf{2 ~ 8 9 7 , 0 0}$ & $\mathbf{3 , 2 0}$ & LOW PERMEABILITY \\
$\mathbf{2 ~ 8 9 9 , 8 0}$ & $\mathbf{2 , 3 0}$ & LOW PERMEABILITY \\
2909,00 & 58,20 & GOOD TEST \\
2910,20 & 18,20 & GOOD TEST \\
2916,50 & 89,60 & GOOD TEST \\
2917,40 & 4,50 & LOW PERMEABILITY \\
2921,30 & 12,30 & GOOD TEST \\
2927,00 & 23,00 & GOOD TEST \\
2934,20 & 32,10 & GOOD TEST \\
2945,10 & 24,60 & GOOD TEST \\
2946,20 & 302,60 & GOOD TEST \\
2947,20 & 28,90 & GOOD TEST \\
\hline
\end{tabular}

\subsubsection{Prediction from core measurement: Decreasing of permeability from lags to tops of} channels

Figure (14) shows between $2972 \mathrm{~m}$ and $2895 \mathrm{~m}$, a decreasing trend (following arrows) of core porosity and core permeability in their values from bottom to top of sandstone bodies (from channels lags to channels tops), This can be explained by the infiltration of overbanks shale in sandy channel tops which allow, after water evaporation, illite to coats quartz grain in sandstone.

Figure (14) show also low core porosity (Blue ellipse) and low core permeability (red ellipse) for top TAGS reservoir it is possibly a compact zone. Next chapter explain with more details this thesis. 


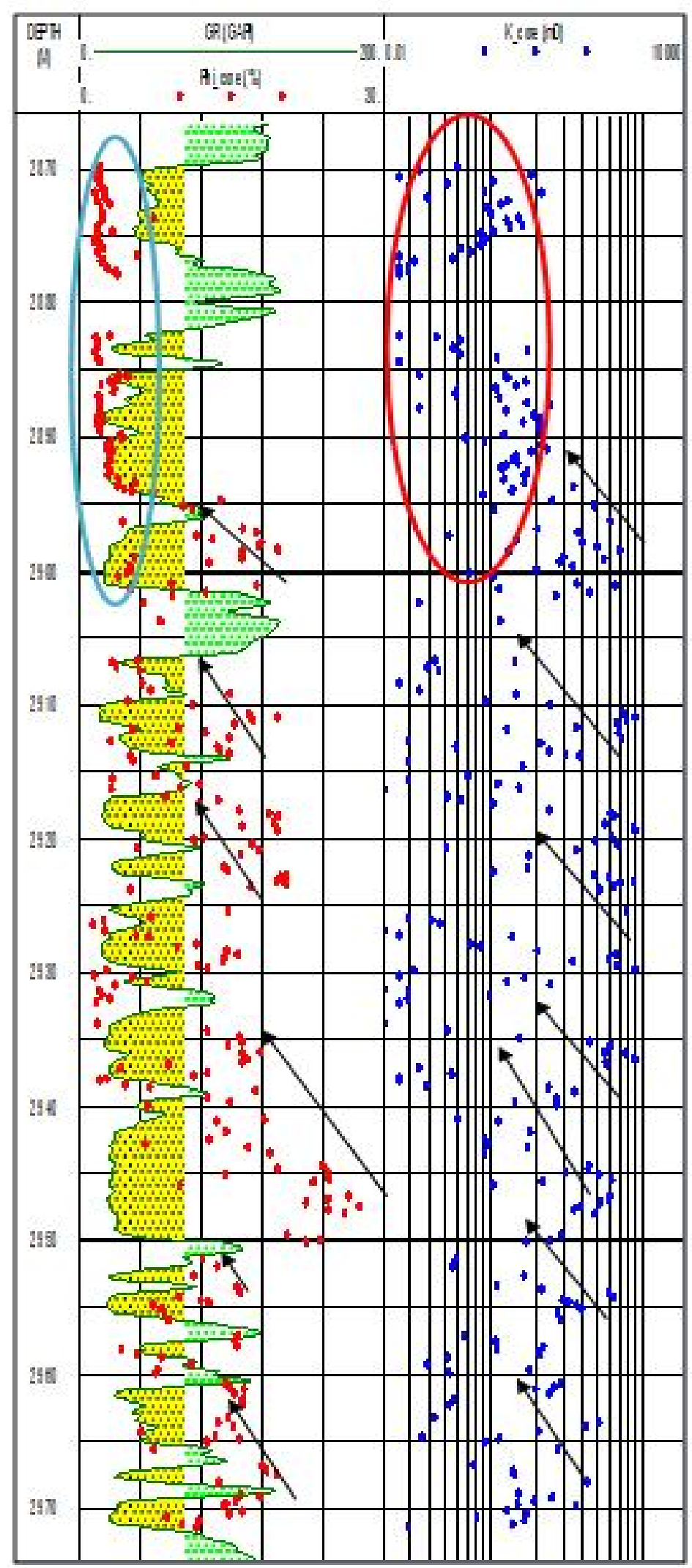

Fig.14. GR combined to core porosity (PHI_core) and core permeability (K_core) showing decreasing trend (following arrows) in their values from bottom to top of sandstone bodies (from channels lags to channels tops). Ellipses indicate low core porosity (Blue ellipse) and permeability (red ellipse) in compact zone. 


\subsubsection{Prediction from core observation: Salty cement and compaction of Top TAGS}

In figure (15) (TOU9 core photos) we can observe compact sandstone mentioned as hard to very hard in corelog description of TOU9 [13].

Compaction is the first process of diagenesis. Usually compaction indicates porosity reduction. Compacted zones may also signify that are highly cemented.

Figure (16) (TOU7 core photo) show a salt filled fracture in sandstone of top TAGS. In TOU7, TAGS is overlayed by about $37 \mathrm{~m}$ of Trias Argileux (Claystone) and $314 \mathrm{~m}$ of Lias Salifère (Salt).

Presence of salt (Halite) as cement and in fracture is certainly the main cause of compact behavior of TAGS in its top. (Fig. 17.)

With correlation to above results given by logs, cross-plots, pressure test results and low core laboratory measurement for porosity and permeability (Fig. 14.), the observed compaction can be considered one of main diagenetic processes caused the decreasing of porosity and permeability of TAGS formation at least in its top.

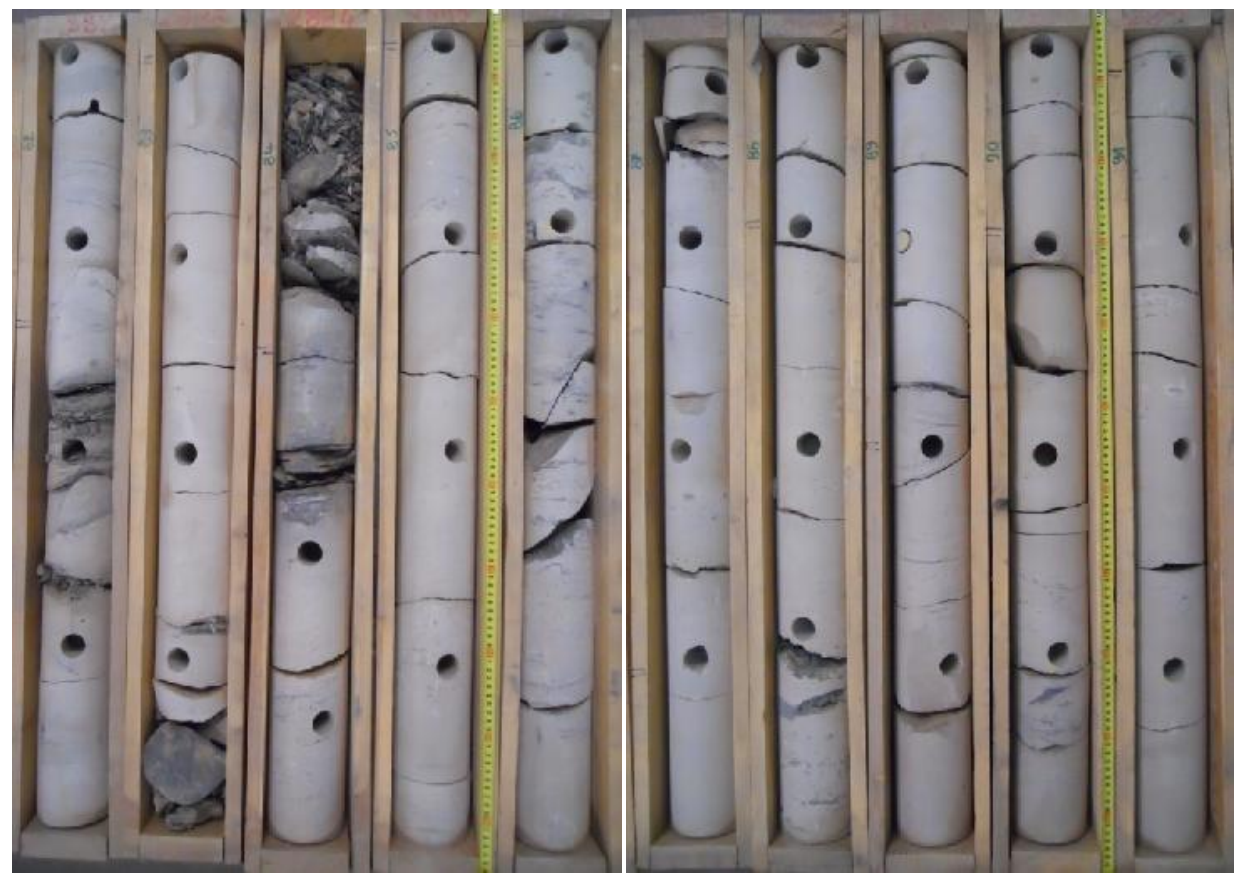

Fig.15. Photos showing highly cemented (Compact) sandstone from 2882 to $2890 \mathrm{~m}$ (TOU9) 


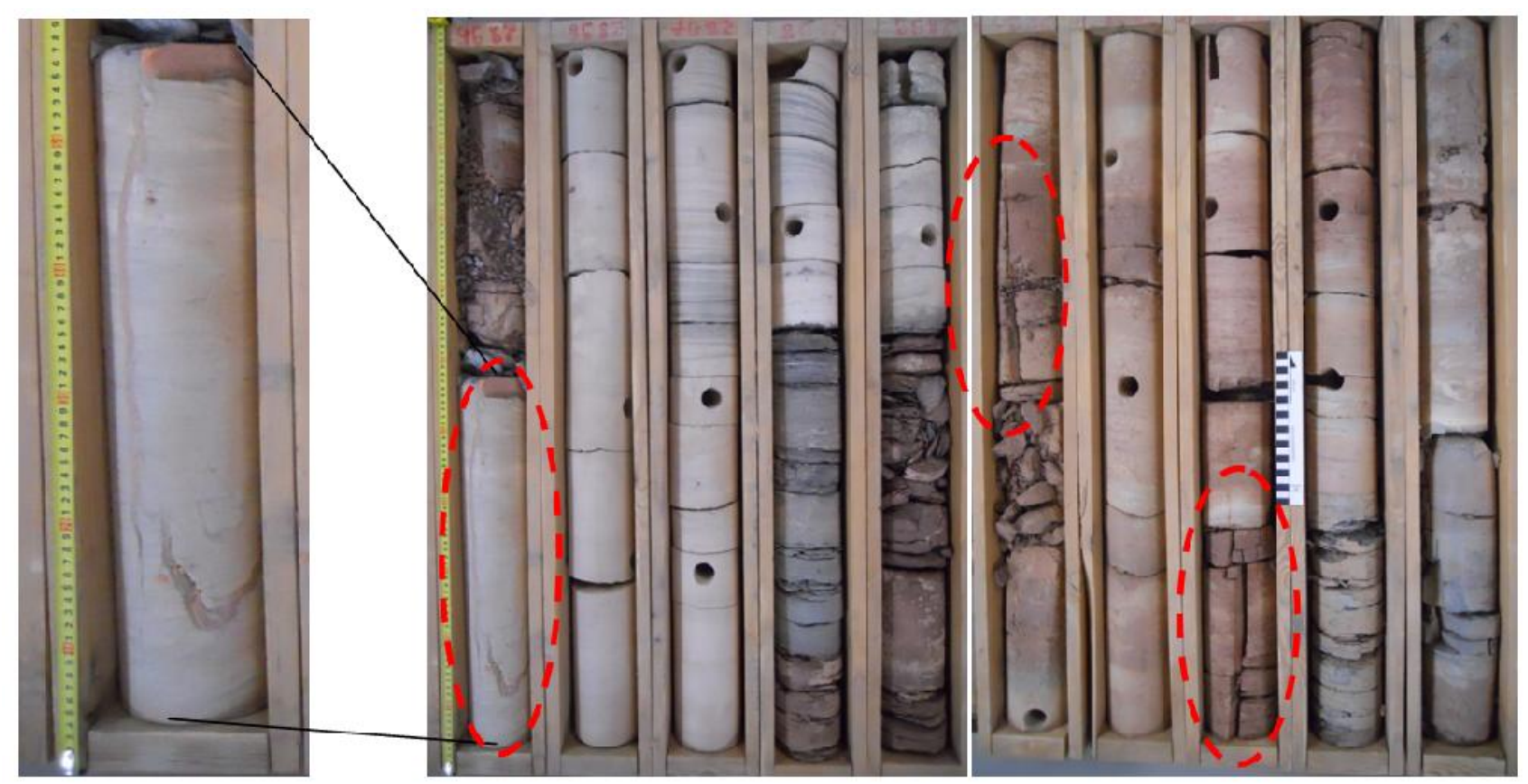

Fig.16. Photos showing reddish salt filled fracture in sandstone of top TAGS, from 2889 to $2894 \mathrm{~m}$

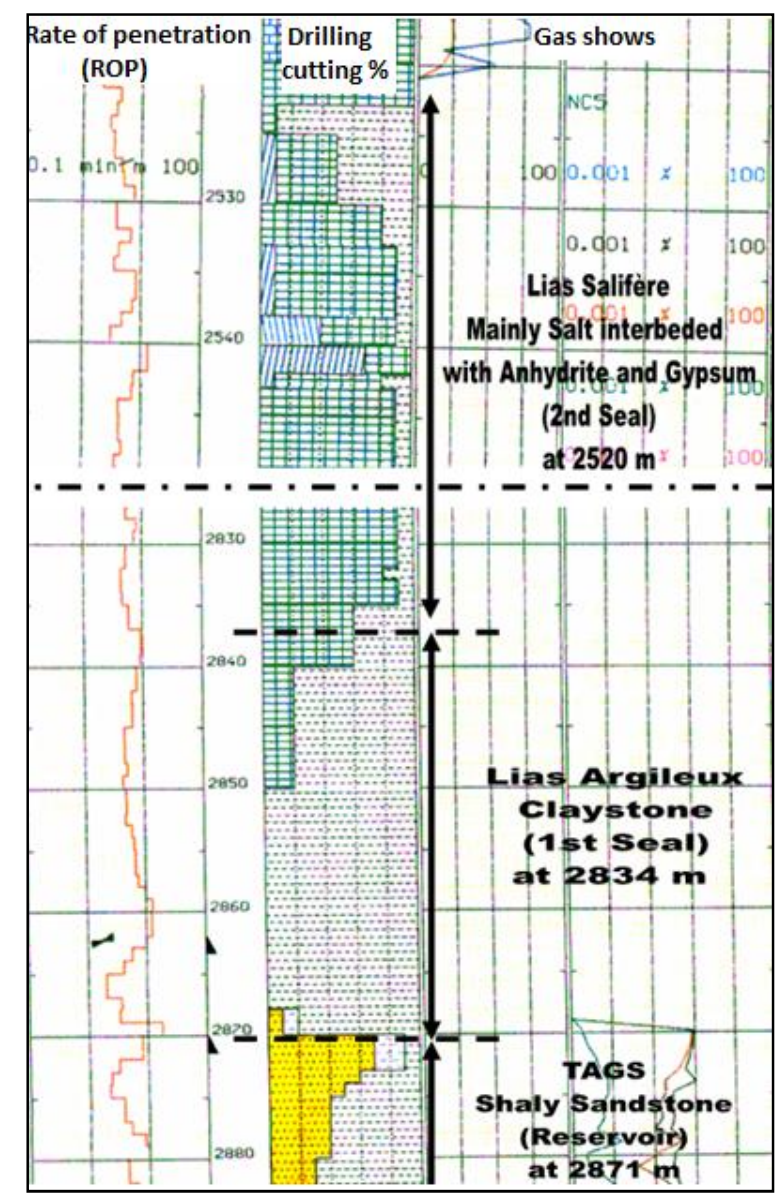

Fig. 17. Master log of (TOU9) showing Top of Lias Salifère (mainly Salt with Anhydrite) at $2520 \mathrm{~m}$, Top Trias Argileux (Claystone) at $2834 \mathrm{~m}$ and top TAGS at $2871 \mathrm{~m}$. Salty formation thickness is estimated at $314 \mathrm{~m}$. 


\section{CONCLUSION}

Based on well logs data, cores measurement and cores photos the present paper affirm that TAGS reservoir in Toual field could have better petrophysical parameters than evaluated by previews petrophysical studies if it is not affected by some diagenetic processes.

The fluvial depositional environment promotes the net thickness reservoir of TAGS. This quality is strongly affected by:

- First, presence in TAGS network of clay minerals (Illite) confirmed by analysis of spectral gamma ray log (SGR) combined with nuclear resonance magnetic log (MRIL) and core measurement. This is explained principally by the inverse correlation between potassium concentration in sandstones and their NMR permeability.

- Second, presence of halite as cement. This is confirmed by well logs and observation on cores photos of halite filling fractures. This is explained by high DT and low RHOB face to sandstones intervals. The thick evaporate sequence of Lias salifère composing the reservoir seal, act certainly on TAGS network by the infiltration of its major mineral (Halite).

The double effect of presence of illite by its bridging as authigenic clay in sandstone network and presence of halite as cement in same network is certainly the origin of permeability decline in TAGS reservoir. The result was $100 \mathrm{mD}$ as maximal value recorded by NMR tool for this permeability.

Low values of cores permeability and cores porosity and very low value of gas mobility in top TAGS indicate the compaction of this top which is confirmed by core photos and wellsite core description noted sandstone in top reservoir as hard to very hard. This reduction of petrophysical properties confirms again the presence of halite at least in top of reservoir.

TAGS porosity seems slightly influenced by illite presence, seeing that porosity correlate normally with potassium concentration in sandstone. On the contrary, halite disturbs pore network as indicated above.

Finally we conclude that influence of TAGS formation diagenesis on its reservoir quality is higher for permeability than porosity. This evidence has been proved mainly by well logs which confirm the success of this method again. 


\section{ACKNOWLEDGEMENTS}

Sonatrach Company ( $\mathrm{SH})$ - Algeria, kindly provides us permission to work on Toual field. This work could not be accomplished without the allocated financial support of Larbi Ben M'hidi University- Oum El Bouaghi Algeria. Thanks come to all its responsibles. We gratefully acknowledge Dr. M.A.K. El-Ghali (SQU) for his critical and constructive reviews of the paper and for post-edited the English style.

We are grateful for the assistance of Sonatrach Company $(\mathrm{SH})$ - Algeria, Sulatan Qaboos University (SQU) - Oman and University of Delft (TUDelft) - Netherlands by their software support and their technical advices. We specified thanks to Mr. Hedjaz Abdelmalek (SH) and Dr. M.E. Donselaar (TUDelft).

\section{REFERENCES}

[1] Galeazzi, S., Point, O., Haddadi, N., Mather, J., Druesne, D. Marine and Petroleum Geology. 27, 2010, 143-178, doi:10.1016/j.marpetgeo.2008.10.002

[2] Askri, H., Belmeheri, A., Benrabah, B., Boudjema, A., Boumendjel, K., Daoudi, M., Drid, M., Ghalem, T., Docca, A.M., Ghandriche, H., Ghomari, A., Guellati, N., Khennous, M., Lounici, R., Naili, H., Takherist, D., Terkmani, M. Geology of Algeria. Well Evaluation Conference - Sonatrach \& Schlumberger, Algiers, 1995, 1-93.

[3] Zeroug, S., Bounoua, N. Lounissi, R., Zeghouani, R., Djellas, N., Kartobi, K., Tchambaz, M., Abadir, S, Simon, P., Fuller, J. Well Evaluation Conference - Sonatrach \& Schlumberger, Algiers, 2007, 1- 489.

[4] Rossi, C., Kälin, O., Arribas, J., Tortosa, A. Diagenesis, provenance and reservoir quality of Triassic TAGI sandstones from Ourhoud field, Berkine (Ghadames) Basin, Algeria. Marine and Petroleum Geology. 19, 2002, 117-142.

[5] Carr, I. D., A sequence stratigraphic synthesis of the north African Mesozoic. Journal of Petroleum Geology. 2003, 26, 133-152.

[6] Bourquin S, Eschard R, Hamouche B. Journal of African Earth Sciences, Elsevier. 2010, 58 (2), 365-386 doi:10.1016/j.jafrearsci.2010.04.003

[7] Turner P, Pilling D, Walker D, Exton J, Binnie J, Sabou N. Sequence stratigraphy and 
sedimentology of the late Triassic TAG-I (Blocks 401/402, Berkine Basin, Algeria). Marine and Petroleum Geology. 2001, 18, 959-981.

[8] Sonatrach PED. Interprétation Pétrophysique du puits TOU7. 2000. Rapport Interne.

[9] Sonatrach EXPL. Implantation du puits TOUP1. 2010a. Rapport Interne.

[10] Sonatrach EXPL. Implantation du puits TOUSW1. 2010b. Rapport Interne.

[11] Serra, O. Well Logging and Geology Editition Technip. 2003, 1-468.

[12] Sonatrach PED. Interprétation Pétrophysique du puits TOU4. 2006. Rapport Interne.

[13] Sonatrach DPGTL. Description des carottes du puits TOU9. 2002. Rapport Interne.

\section{How to cite this article:}

Mazouz E, Hamimed M, Yahiaoui A, El-Ghali M A K. Prediction of diagenesis and reservoir quality using wireline logs: Evidence from the Upper Triassic (Raethian) fluvial reservoir TAGS - Toual field, Gassi Touil area, SE Algeria. J. Fundam. Appl. Sci., 2017, 9(2), 808-828. 